\title{
Medievalista
}

\section{Portugal, os clássicos e a cultura europeia}

colóquio de homenagem a A. A. Nascimento no seu $80^{\circ}$ aniversário

\section{Adelaide Miranda e Isabel Barros Dias}

\section{(2) OpenEdition}

\section{Journals}

\section{Edição electrónica}

URL: http://journals.openedition.org/medievalista/2928

DOI: $10.4000 /$ medievalista.2928

ISSN: 1646-740X

Editora

Instituto de Estudos Medievais - FCSH-UNL

\section{Refêrencia eletrónica}

Adelaide Miranda e Isabel Barros Dias, « Portugal, os clássicos e a cultura europeia », Medievalista [Online], 27 | 2020, posto online no dia 01 janeiro 2020, consultado o 23 setembro 2020. URL : http:// journals.openedition.org/medievalista/2928; DOI : https://doi.org/10.4000/medievalista.2928

\section{(c) (7) \&)}

Mediavalista está licenciado com uma Licença Creative Commons - Atribuição-NãoComercial 4.0 Internacional. 
Título / Title (Português e Inglês): Portugal, os clássicos e a cultura europeia: colóquio de homenagem a $\mathrm{A}$. A. Nascimento no seu $80^{\circ}$ aniversário Autor(es) / Author(s): (a) Adelaide Miranda; (b) Isabel Barros Dias Afiliação institucional / Institutional affiliation (Universidade, Faculdade, Departamento ou Unidade de Investigação / University, Faculty, Department or Research Centre): (a) Instituto de Estudos Medievais, Faculdade de Ciências Sociais e Humanas, Universidade Nova de Lisboa; (b) Universidade Aberta e Instituto de Estudos e Literatura e Tradição e Instituto de Estudos Medievais, Faculdade de Ciências Sociais e Humanas, Universidade Nova de Lisboa

Código postal / Postcode; Cidade / City; País / Country: 1069-061 Lisboa, Portugal ORCID: (a) http://orcid.org/0000-0002-7581-3888 ; (b) https://orcid.org/0000-0003-34796660

Email Institucional / Institutional email: (a) adelaide@fcsh.unl.pt ; b) Isabel.Dias@uab.pt Fonte: Medievalista [Em linha]. Direc. Bernardo Vasconcelos e Sousa. Lisboa: IEM. Disponível em:

http://www2.fcsh.unl.pt/iem/medievalista/MEDIEVALISTA27/mirandadias27V2.html

ISSN: 1646-740X

Data recepção do artigo / Received for publication: 2 de Setembro de 2019 


\title{
4
}

\section{Portugal, os clássicos e a cultura europeia: colóquio de homenagem a A. A. Nascimento no seu $80^{\circ}$ aniversário}

\author{
Adelaide Miranda, Isabel Barros Dias
}

Ao longo de quatro dias, com início a 16 de Julho, decorreu na Faculdade de Letras da Universidade de Lisboa, promovido pelo Centro de Estudos Clássicos, uma homenagem a Aires Augusto Nascimento à qual foi dado o título "Portugal, os clássicos e a cultura europeia: colóquio de homenagem a A. A. Nascimento no seu $80^{\circ}$ aniversário". Este evento culminou com a celebração dos oitenta anos do homenageado, no dia 20 . Num clima de reunião de amigos promovido pela Comissão organizadora (Arnaldo Espírito Santo, Cristina Pimentel e Rodrigo Furtado) e com o Professor sempre presente, cerca de 80 investigadores nacionais e internacionais cujos percursos, de alguma forma, com ele se cruzaram, deixaram os seus testemunhos de relações de amizade e de gratidão pelo espírito de partilha de conhecimento e de estímulo a jovens investigadores. De assinalar, pois, a confluência que se verificou entre jovens e menos jovens investigadores, alunos e discípulos do homenageado, a par de colegas e amigos de longa data.

O Colóquio revelou-se de extrema importância para a comunidade científica, dadas as muitas novidades que foram apresentadas. Os temas abordados foram múltiplos e diversificados, em sintonia com as áreas de estudo nas quais Aires Augusto Nascimento produziu trabalho de investigação: a Literatura Latina Medieval e do Renascimento, a Filologia, a História e a Cultura, a História do Livro e a Codicologia, a História da Arte, as Bibliotecas e os Arquivos, a Literatura de Viagens, os Mosteiros e as Ordens monásticas... As conferências estiveram a cargo de José Manuel Díaz de Bustamante, Thomas Earle, Joaquim Cerqueira Gonçalves, Carmen Codoñer Merino e Paolo Fedeli, investigadores de longa e meritória carreira. 
A quantidade e qualidade dos investigadores que afluíram à homenagem realizada a Aires Augusto Nascimento assinalou indelevelmente a marca que este estudioso tem vindo a deixar, não só diretamente, nas letras portuguesas, como também indiretamente, graças às várias gerações de pesquisadores que com ele têm vindo a trabalhar. Nascido em Palhais - Trancoso, em 1939, Aires A. Nascimento licenciou-se em Filologia Clássica e doutorou-se em Linguística Latina, tendo sido professor catedrático da Faculdade de Letras da Universidade de Lisboa, onde exerceu diversos cargos, e coordenador do Centro de Estudos Clássicos. Foi diretor da conceituada Revista Euphrosyne e autor de uma imponente e significativa obra de pesquisa, cujos frutos continuam a marcar a agenda da investigação em Portugal. Medievalista, Classicista, Humanista... Aires Augusto Nascimento, atualmente jubilado, tem sido um exemplo de estudioso que não se preocupa só com o seu percurso. A atenção que sempre dedica a jovens investigadores, com os quais não hesita em partilhar conhecimentos, tem dado frutos significativos, amplamente demonstrados na Homenagem que lhe foi oferecida e que aqui noticiamos.

Para informações mais detalhadas sobre o percurso pessoal e científico de Aires Augusto Nascimento, bem como algumas fotografias do colóquio de homenagem que lhe foi organizado, ver: http://www.filorbis.pt/AiresAugustoNascimento.pdf . 


\section{COMO CITAR ESTE ARTIGO}

\section{Referência electrónica:}

MIRANDA, Adelaide; DIAS, Isabel Barros - "Portugal, os clássicos e a cultura europeia: colóquio de homenagem a A. A. Nascimento no seu 80ªniversário”. Medievalista 27 (Janeiro - Junho 2020). [Em linha] [Consultado dd.mm.aaaa]. Disponível em http://www2.fcsh.unl.pt/iem/medievalista/MEDIEVALISTA27/miranda-dias27V2.html ISSN 1646-740X.

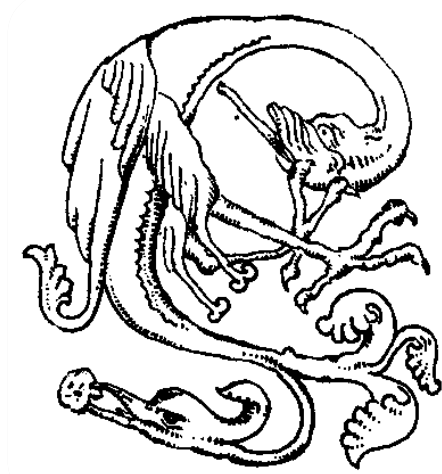

